\title{
Arquetipos femeninos y masculinos en la novela Entre visillos de Carmen Martín Gaite. Un análisis desde la etnoliteratura ${ }^{1}$
}

\author{
Feminine and masculine archetypes in Carmen \\ Martín Gaite's Entre visillos. An analysis from \\ ethnoliterature
}

Sonia Cajade Frías

Departamento de Antropología Social y Cultural

UNED. Madrid

RESUMEN

El propósito de este artículo es analizar desde una perspectiva etnoliteraria la novela Entre visillos (1958) de Carmen Martín Gaite en relación con el contexto social y cultural de la España de posguerra de los años cincuenta. El objetivo del trabajo consiste en estudiar los arquetipos femeninos y masculinos que se proyectan a través de la novela y su conexión con los modelos de género propuestos por la ideología dominante del nacional-catolicismo, muchos aún vigentes en la sociedad actual. Se trata así de explorar cómo el contexto sociocultural de la época se refleja en la novela y cómo a su vez la propia obra literaria, como producto cultural específico, posee la capacidad de proyectarse sobre esa misma realidad social, contribuyendo así a re-construirla, concretamente a través de la creación de nuevos arquetipos de género que proponen modelos de identidad alternativos.

Palabras clave: Arquetipos femeninos y masculinos, Etnoliteratura, Postguerra española, Nacionalcatolicismo, Construcción de identidad.

\footnotetext{
${ }^{1}$ Deseo hacer constar mi agradecimiento por su estímulo positivo y sus valiosos comentarios sobre este trabajo a Rafael Llavona, a los alumnos del curso de doctorado por él impartido en la Universidad Complutense en el curso 2006/2007 sobre "El imaginario social sobre la diversidad cultural: Una aproximación desde la Etnoliteratura" (Encarna López Matarín, Laura Llera, Montserrat Toll, Sergio García Cañas, J. Antonio Orellana, A. Javier Rivallo y Lucía Torres). También de modo especial a Esperanza Guisán, María Cátedra, Beatriz Moncó, Ester Massó, Sandra Santos, María Peláez, Jennifer Kresse, Thérèse Ravit, Sandra Fernández y Berta Delgado. Este trabajo fue presentado como ponencia en el Congreso Women's Worlds 2008 (Madrid, 3-9 julio 2008).
} 


\section{SUMMARY}

The aim of this article is to analyze from the perspective of ethnoliterature the novel Entre visillos (1958) by Carmen Martín Gaite in relation to the Spain's social and cultural context in the 1950s. The objective of the work consists of studying the feminine and masculine archetypes that the novel projects, in connection with the gender-related models that National-Catholicism promoted at the time. Many of these models are still prevalent in Spain. For her the novel, as it encapsulated the socio-cultural context of the 1950s, had by itself, as a specific literary product, the power of impinging upon and re-constructing that social reality, especially by producing new archetypes of gender on which to offer alternate models of identity.

Key words: Feminine and Masculine Archetypes, Ethno-literature, Spain's Post-War Years, National-Catholicism, Construction of Identity.

\section{INTRODUCCIÓN}

El propósito de este artículo es analizar desde la perspectiva de la antropología de la literatura la novela Entre visillos (1958) de Carmen Martín Gaite, en relación con el contexto social y cultural de la España de posguerra de los años cincuenta. El objetivo del trabajo consiste en estudiar los arquetipos femeninos y masculinos que se proyectan a través de esta novela y su conexión con los modelos de género propuestos por la moral del nacionalcatolicismo, muchos de los cuales continúan vigentes en la sociedad actual. Se trata así de explorar cómo el contexto sociocultural de la época se refleja en esta novela, y mostrar también cómo a su vez la propia obra literaria posee la capacidad, como producto cultural específico, de proyectarse sobre esa misma realidad social, contribuyendo de este modo a re-construirla, a través de la creación de nuevos arquetipos de género que proponen modelos de identidad alternativos.

Tanto la creación de esta obra como el tiempo de acción dentro de la novela se sitúa en el contexto social de la España de los años cincuenta, es decir, en la España franquista de la segunda posguerra. Aunque en los años cincuenta se produjo en comparación con la década anterior cierto aperturismo — simbolizado con la entrada de España en la ONU en 1955-, España continúa aislada con respecto a los demás países europeos, en los que mayoritariamente se habían establecido regímenes liberales y democráticos tras la Segunda Guerra Mundial. Otros componentes de este contexto social eran la pobreza, consecuencia de los destrozos de la guerra civil y de una economía atrasada, la división del país en dos Españas, la de los vencedores y los vencidos, el peso del recuerdo del enorme número de exiliados, muertos y desaparecidos durante la guerra civil; así como, paralelamente, las emociones de resentimiento, tristeza, rencor e incluso ven- 
ganza hacia los que se sabía que habían estado en uno u otro bando durante la contienda. El gobierno franquista puso gran empeño en establecer durante esos años la moral del nacional-catolicismo, combinación de ideas fascistas de la Falange y del conservadurismo tradicional: una moral fuertemente represiva del individuo, que se basaba en los valores de la patria, la familia y la Iglesia. Fue especialmente dura respecto a la mujer, que después de haber alcanzado la experiencia de libertad en distintos campos de su vida durante la II República, esta nueva moral del nacional-catolicismo le concede sin embargo un único papel legítimo, el de madre y esposa, "ángel del hogar", sometida en todo momento al hombre. Sin embargo, en la misma década de los cincuenta comienzan también a aparecer algunas protestas organizadas contra el Régimen, como la revuelta de estudiantes universitarios antifranquistas contra miembros del SEU (Sindicato Español Universitario) en la Universidad Central de Madrid, en 1956, o la huelga de tranvías en Barcelona en 1951.

En este contexto franquista represivo de las libertades se sitúa esta novela, que relata cómo vive un grupo de jóvenes en una ciudad de provincias durante esos años, a qué dedican su tiempo, cuáles son sus proyectos de vida, sus concepciones, acciones y creencias, y cómo construyen su identidad fuertemente segregada por la división de género de acuerdo con la moral nacionalcatólica. Sin embargo, en este ambiente opresivo hay lugar también para las rebeliones o "resistencias", como trataré más adelante, tanto por parte de la escritora de esta novela, al escoger la vía literaria para desarrollar a través de ella su particular "ritual de resistencia" (Comaroff y Comaroff 1991) como también por parte de los personajes de la novela, que desafían con sus discursos y prácticas ciertos arquetipos de género propugnados por el nacionalcatolicismo ${ }^{2}$.

Resulta por otra parte también interesante la relación entre lo que acontece en Entre visillos y la biografía de su autora, la conexión por tanto entre la realidad y la ficción. La propia Martín Gaite declara en una entrevista en 1979:

Entre visillos lo escribí como una especie de rechazo de ese mundo provinciano del que yo huía. Yo tenía veintitantos años y acababa de llegar a Madrid. Hay una

\footnotetext{
${ }^{2}$ Para los Comaroff, los "rituales de resistencia" se plantean en situaciones en las que el poder hegemónico es tan dominante que no es posible realizar una confrontación directa. En estos contextos la lucha principal se da por la "posesión del signo", y los rituales de resistencia tienen la potencialidad de quebrar el sistema de representaciones hegemónico, contribuyendo de este modo a hacer conscientes a las personas de la opresión que sufren, abriendo así la imaginación hacia nuevos mundos posibles. De este modo, el poder, aún el más hegemónico, siempre presenta fisuras o puntos débiles, como pone de manifiesto la existencia de este tipo de rituales.
} 
crítica, aunque sin crueldad, de ese mundo pequeño y demasiado cerrado de mi infancia y juventud" (Fernández 1979: 171. Cit. en Jurado Morales 2003: 57-58).

En el prólogo a su obra de teatro La hermana pequeña, Martín Gaite habla de los temas comunes que preocuparon a los autores de su generación, presentes también en Entre visillos:

[...] el desajuste entre los sueños y la realidad, el afán por emigrar de la provincia a las ciudades grandes, la odisea del crecimiento para los seres débiles y sedientos de amor, el equilibrio inestable entre claudicar o mantener la bandera del inconformismo. Y sobre todo el miedo a la libertad, a ir madurando a solas en una sociedad hostil, que sólo protege a los que se insertan en ella y obedecen sus leyes sin rechistar (Martín Gaite 1999: 9).

Esta conexión, que refleja la peculiar relación y las sutiles fronteras que existen siempre entre la realidad y la ficción, aparece también en las novelas de otras escritoras del momento, como Aguas muertas (1945) de D. Boixados, o Nada (1944) de C. Laforet, que narra la vida de una joven que va a estudiar a Barcelona donde vive en casa de unos familiares, tal como le ocurrió a esta autora en su vida real durante esos mismos años.

De manera semejante a Nada de Laforet, la novela Entre visillos pone de manifiesto la imposibilidad de los individuos para cambiar por ellos mismos la moral del nacionalcatolicismo imperante en el entorno sociocultural que les rodea. Parece, pues, como sugieren ambas novelas, que la única salvación posible es a nivel individual, a través de la huida a otro lugar, que sea potencialmente más favorable para la realización de los deseos y los proyectos de vida de los protagonistas. El título de esta novela es en este sentido significativo, como también los de otras obras literarias de la misma época, como Aguas muertas (Dolores Boixados, 1944), Perdimos la primavera (Eugenia Serrano, 1946), Nada (Carmen Laforet, 1944), o Cinco sombras (Eulalia Galvarriato, 1946): todas ellas hacen referencia a espacios cerrados donde la vida se estanca, donde algo importante se malogra, se pudre: la falta de estímulos vitales, la pérdida de posibilidades de florecimiento y plenitud de vida, en donde el balance de esa trayectoria vital es sucintamente "nada" y el porvenir es simplemente incierto...

En este contexto social de la España de los años cincuenta se alza, sin embargo, a través de productos literarios como Entre visillos, la creación de determinados arquetipos de mujer que contrastan frontalmente con los del "ángel del hogar", "madre sacrificada" y "esposa abnegada" propuestos por la moral del nacionalcatolicismo. Son las "chicas raras" de las que habla Martín Gaite, con el ejemplo de Natalia o Elvira en la presente novela, que tienen su paralelismo en otros "chicos raros" como el personaje de Pablo en esta misma obra - $\mathrm{O}$ el de David en la novela Ritmo lento también de 
esta autora. De acuerdo con la conceptualización de Martín Gaite, la "chica rara" se caracteriza porque no acata pasivamente las normas convencionales al uso, sino que cuestiona su validez desde criterios personales y, en el caso de no estar de acuerdo con aquéllas, se rebela de algún modo contra esas normas así como contra los agentes sociales que las representan. Así lo expresa la propia Martín Gaite:

[...] la "chica rara", cuyo reinado inauguró la heroína de Carmen Laforet [Andrea, en Nada], no sólo rechazaba la retórica idealización de "sus labores" predicada por la Sección Femenina, sino que empezaba a convivir con una idea inquietante, difícil de encajar y de la que cada cual se defendía como podía: la de que no existe el amor de novela rosa (Martín Gaite 1992b: 122).

A juicio de esta misma autora

este paradigma de mujer, que de una manera o de otra pone en cuestión la "normalidad" de la conducta amorosa y doméstica que la sociedad mandaba acatar, va a verse repetido con algunas variantes en otros textos de mujeres como Ana María Matute, Dolores Medio y yo misma [...] De ahora en adelante, las nuevas protagonistas de la novela femenina, capitaneadas por el ejemplo de Andrea, se atreverán a desafinar, a instalarse en la marginación y a pensar desde ella; van a ser conscientes de su excepcionalidad, viviéndola con una mezcla de impotencia y orgullo" (Ibid. 111-112).

Puede contemplarse así cómo a través de la vía literaria determinadas escritoras de esta época se rebelan contra la moral establecida por el Régimen, practicando, como señalaba anteriormente, una especie de "ritual de resistencia" que desafía las identidades convencionales y propone modos de ser alternativos. En este sentido, un punto de interés central en el análisis antropológico de estas novelas radica en observar cómo el contexto social de la moral franquista se proyecta en las obras literarias, y cómo a su vez éstas, a través de una relación dialéctica, poseen la potencialidad de recrear la realidad social, ofreciendo nuevos ideales susceptibles de ser legitimados socialmente y de producir así en la práctica nuevos modos de identidad. De ahí el interés de realizar un análisis etnoliterario en torno a estas cuestiones, susceptible de revelar importantes aspectos estructurales de la realidad social, concretamente, en el caso que nos ocupa, los roles de género presentes en el contexto social de la España franquista. Este tipo de análisis sobre obras literarias ha sido sin embargo escasamente desarrollado desde la antropología social y cultural, de ahí que el planteamiento que presento en este trabajo no siga un protocolo específico o un marco teórico ya establecido, sino que más bien se trata de un desarrollo personal consecuente con mi formación en antropología social y cultural y mis intereses teóricos. Entre los trabajos que abordan la literatura desde una perspectiva antropo- 
lógica cabe destacar los trabajos de M. de la Fuente (1994) y M. de la Fuente y M. A. Hermosilla (1997), C. Lisón (1995), así como los recientes números monográficos dedicados a Etnoliteratura: Lecturas de la condición bumana por la Revista de Dialectología y Tradiciones Populares, coordinado por Hermosilla, Castaño y Díaz (2005), y a Antropología y Literatura por la Revista de Antropología Social, coordinado por S. Castillo (2008). Desde la perspectiva de la teoría de la literatura y la literatura comparada, cabe también resaltar las obras de J. del Prado (2000) y J. M. Pozuelo Yvancos (1993).

\section{ENTRE VISILLOS}

Escrita por Carmen Martín Gaite (1925-2000) entre 1955 y 1957, Entre visillos ganó el Premio Nadal 1957 y fue publicada al año siguiente. La novela narra la vida de la clase burguesa en el contexto de la posguerra de los años cincuenta. La acción se desarrolla en una ciudad de provincias que se reconoce fácilmente como Salamanca — aunque la autora no lo diga de modo explícito-, precisamente la ciudad donde Martín Gaite nació, también en el seno de una familia burguesa, y vivió hasta los veinticuatro años, fecha en la que se trasladó a Madrid para hacer su doctorado, convirtiéndose a partir de entonces en su lugar de residencia permanente.

Entre visillos describe la vida de los jóvenes de la burguesía salmantina, especialmente de las mujeres. A través de las historias que les suceden a los personajes, la obra da testimonio de su modo de vida, de cómo transcurre su vida cotidiana, a qué se dedican, qué hacen habitualmente, cuáles son sus pensamientos, sus deseos e inquietudes, dentro de ese contexto social y cultural específico. Con la distancia que dan los años, la propia autora pone de relieve ese valor testimonial, y por tanto antropológico, que tiene esta novela como testigo de cómo era la vida de la clase burguesa provinciana en la España de los años cincuenta:

Esta novela plasma muy bien, casi sin yo darme cuenta, porque lo tenía muy reciente, toda la vida de las chicas casaderas provincianas de esos momentos. Hasta tal punto, que creo que es una novela que tiene ahora mucho más valor de testimonio que entonces lo tuvo. Hace unos años que la pusieron por televisión [en 1973] [...] me contaban que había muchas señoras que estaban pegadas a la televisión esperando a que se contara el capítulo siguiente, porque claro, se estaba contando su vida. Señoras que tuvieron cincuenta años en el año 1973, que hubieran sido jóvenes cuando yo, todo eso les decía mucho, mucho más que cuando yo publiqué la novela, que como todavía eran jóvenes, no veían tanto el reflejo ni los cambios. Es decir[(...] es sobre todo el valor testimonial que tiene hoy día (Martín Gaite 1980). 
En línea con la evolución que fue tomando la literatura española de esos años hacia el objetivismo y el realismo social, en Entre visillos el protagonista es colectivo, con distintas historias paralelas, desarrolladas por diferentes personajes que guardan relación entre sí. Aparece además un predominio del diálogo y del lenguaje coloquial y la narración se sitúa mayoritariamente en el tiempo presente, de tal modo que los personajes hablan acerca de aquello que les está ocurriendo en ese momento o les acaba de ocurrir. Pero aunque se trata de una novela coral, en ella destacan claramente cuatro personajes: Pablo Klein, Natalia, Julia y Elvira.

El equilibrio de esa vida provinciana en la que se sitúa la novela se va a romper con la llegada de Pablo Klein, el nuevo profesor de alemán del Instituto, que representa la figura del "extranjero" que llega a la ciudad y que va a suponer un factor de desequilibrio respecto al juego de fuerzas actanciales que operan habitualmente en ese contexto sociocultural. Pablo Klein tiene treinta años y ha vivido en distintos lugares fuera de España - París, Berlín, Italia-, por lo que su mentalidad es muy diferente al estilo de vida de la burguesía de provincias de los años cincuenta. De ahí que la mirada de Pablo sobre la ciudad y sus habitantes, a través de sus observaciones y de las relaciones que establece con ellos, resulta, por contraste, muy reveladora en cuanto al modo de vida característico de una ciudad de provincias de la posguerra española, especialmente de la clase burguesa. Pablo Klein había estado anteriormente viviendo en Salamanca durante un tiempo cuando era niño con su padre, un pintor viudo, amigo del director del Instituto que ahora ha contratado a Pablo para dar clases de alemán.

Otro de los personajes principales de la novela es Natalia (Tali), una chica de dieciséis años, huérfana de madre, que va a empezar su último curso de bachillerato en el Instituto, donde tendrá de profesor a Pablo. Tiene dos hermanas mayores, Julia y Mercedes; las tres viven con su padre y su tía Concha, que es muy estricta y las vigila estrechamente. Julia, de veintisiete años, tiene el problema de que el novio con el que se va a casar, Miguel, vive en Madrid y quiere que ella vaya a vivir también allí para estar con él, pero la familia de Julia — su padre y la tía Concha- no la dejan, por lo que ella se siente presionada por ambas partes. Por último, Elvira es la hija del director del Instituto donde va a trabajar Pablo; su padre acaba de morir y ella guarda luto. En la novela hay tres narradores, uno omnisciente y los otros dos en primera persona: uno de ellos es Natalia, a través de su diario, y el otro es Pablo Klein, que va narrando las impresiones que le produce la ciudad y los sucesos que le van ocurriendo. La acción transcurre a lo largo de tres meses, desde mediados de septiembre hasta mitad de diciembre, al inicio de las vacaciones de Navidad.

La novela comienza con el diario de Natalia, donde cuenta que su me- 
jor amiga, Gertru, de su misma edad, se va a casar dentro de varios meses con Ángel, un chico mayor que ella que es piloto. Todo el mundo felicita a Gertru porque piensa que Ángel es un "buen partido". Gertru le comenta a Natalia que este año no se va a matricular en el Instituto para el último curso de bachillerato, porque a su novio no le gusta la idea de que siga estudiando. Está ilusionada porque dentro de unos días se "pone de largo" en una fiesta del Aeropuerto, a la que ha invitado a Natalia, pero ésta no quiere ir y se excusa ante su amiga diciéndole que no ha conseguido convencer a sus dos hermanas para que vayan con ella - Gertru no sabe que, en realidad, de lo que le ha costado convencerlas a Natalia es de lo contrario, de que no vayan.

Natalia es una de las "chicas raras" de la novela, del tipo de Andrea en Nada de Carmen Laforet. Le aburren las conversaciones de sus hermanas con las amigas, que tratan siempre sobre los mismos temas (los novios, la ropa, el Casino, los cotilleos sobre la gente). A Natalia todas las amigas de sus hermanas le parecen la misma, puesto que considera que todas ellas hablan y se comportan de igual modo. Natalia hace lo posible para no tener que estar con ellas, para poder estar sola y hacer las cosas que le gustan (leer, dibujar, ir a andar en bicicleta), pero sus hermanas tratan de que se integre en su grupo. Estas intentan convencerla para que se "ponga de largo", para lo cual le han comprado ya la tela del vestido, sin embargo Natalia se niega. "Ella que se descuide y verá” (Martín Gaite 1991: 23), le dice su hermana Mercedes a las amigas, comentándoles de paso que Natalia es una "salvaje", que "qué manía tiene de estar siempre en otro lado, como la familia escocida" (Ibid.: 21). A Natalia tampoco le gusta ir al Casino, una de las ocupaciones favoritas de los jóvenes burgueses de esta ciudad, donde ven y se dejan ver, bailan, flirtean y cuentan chismes. En el Casino las jóvenes habitualmente esperan sentadas a que el chico que les gusta las saque a bailar; para esto las chicas de esta novela han aprendido que tienen que ser expertas en saber "dar pie", esto es, en mostrar cierto interés por el muchacho, pero sin excederse, pues una "chica bien" tiene que saber también "darse a valer", porque si no corre el riesgo de que piensen de ella que es una "fresca". Natalia, por el contrario, busca siempre que puede los espacios abiertos, el contacto con la Naturaleza.

Las conversaciones sobre los novios y el matrimonio son una constante en toda la novela, sobre todo entre las muchachas. A las chicas jóvenes, las "chicas casaderas", lo que más les preocupa es encontrar "un buen partido". En este sentido, la novela pone de manifiesto que el mejor partido está representado en la sociedad de posguerra por el chico que prepara oposiciones a notaría: 
Las chicas sin novio andaban revueltas a cada principio de temporada, pendientes de los chicos conocidos que preparaban oposición de Notarías. Casi todas estaban de acuerdo en que era mejor salida la carrera de Derecho, la cosa más segura. Otras, las menos, ponían algunos reparos.

- Hija, pero también, te casas con un notario y tienes que pasar lo mejor de tu vida rodando por dos o tres pueblos. Cuando quieres llegar a una capital, ya estás cargada de hijos, y vieja y no tienes humor para divertirte. Una paleta para toda tu vida.

-Sí, déjate de cuentos. Pero ganan muchísimo. Y si hacen una buena oposición y tienen número alto, pueden empezar por capital, y entonces ya no te digo nada. A lo mejor a los treinta años, estás casada con un notario de Madrid, ¿tú sabes lo que es eso?

—Sí, sí, a los treinta años...

Se veían del brazo de un chico maduro, pero juvenil, respetable, pero deportista, yendo a los estrenos de teatros y a los conciertos del Palacio de la Música, con abrigo de astracán legítimo; sombrerito pequeño. Teniendo un círculo; seguras y rodeadas de consideración. Masaje en los pechos después de cada nuevo hijo. Dietas para adelgazar sin dejar de comer. Y el marido con Citröen. (Martín Gaite 1991: 195).

Como refleja la novela, el mayor miedo que tenían las chicas de posguerra era quedarse solteras, tal como intuyen las chicas que le va a pasar a Mercedes, la hermana de Natalia, pues va a cumplir treinta años y está todavía sin novio, según las amigas a causa de su mal carácter: "Y es lo malo, que ya no se casa, qué se va a casar. Con el carácter que tiene. ¿Tú crees que va a encontrar quien la aguante" (Ibid.: 226). Martín Gaite analiza en Usos amorosos de la posguerra española la figura de la "solterona", término que "llevaba implícito tal matiz de insulto que se adjudicaba a espaldas de la aludida" (1992a: 43):

De las mujeres de la familia, del servicio doméstico, amigas o vecinas a quienes se les había pasado o se les estaba pasando "la edad de casarse", los adultos hablaban con una mezcla de piedad y desdén. Incluso se las condenaba de antemano, como si algunas hubieran nacido ya marcadas por aquel estigma. "Esa se queda para vestir santos. Y si no, al tiempo. Lo lleva escrito en la cara". Generalmente, más que a una descarada fealdad, se aludía a un gesto, a una actitud. La que "iba para solterona" solía ser detectada por cierta intemperancia de carácter, por su intransigencia o por su inconformismo. Analizar las cosas con crudeza o satíricamente no parecía muy aconsejable para la chica que quisiera "sacar novio". Se les pedía ingenuidad, credulidad, fe ciega. (Ibid.: 37-38).

Entre visillos pone en evidencia cómo en la sociedad de posguerra el tema del matrimonio no era una cuestión privada sobre la que cada individuo pudiera decidir libremente (si casarse o no, y de hacerlo con quién), sino que se trataba de una cuestión pública, donde la familia —y el entorno social en general- tenían no sólo el derecho, sino también el deber de 
controlar, la prerrogativa de aprobar o desaprobar al posible pretendiente. Como sostiene Martín Gaite en su estudio sobre las costumbres amorosas de la posguerra española "los padres solían estar bastante al tanto de los posibles candidatos a la mano de sus hijas. Un chico que estuviera acabando la carrera o haciendo oposiciones a algo, y que además fuera serio y de familia conocida era el más aconsejable, un hombre estable, responsable, de porvenir. Otro extremo en el que se insistía machaconamente era en el de la diferencia de edad" (1992a: 199)33, considerando conveniente que ellos tuvieran cinco o diez años más que ellas. El control social se dirigía especialmente hacia las chicas que "corrían el riesgo" de quedarse solteras:

Ni la familia, ni las amigas, ni los consultorios sentimentales se dirigían a la chica "que iba para soltera" con otro propósito que el de insuflarle, de mejor o peor fe, la ilusión de que algún día podía dejar de serlo, de estimularla en la competición con las demás aspirantes al rango de casadas. Vocación de soltera no se concebía que la pudiera tener nadie. Se trataba de animar a las que se creyeran en inferioridad de condiciones para que no perdieran la esperanza en la victoria, de alistarlas, en fin, para una causa que se consideraba de interés general. (Ibid.: 42).

El prototipo de "chica casadera" está representado en Entre visillos por Gertru, la amiga de Natalia, dada su juventud, ingenuidad, belleza e inexperiencia. Ángel, el novio de Gertru, le habla a su amigo Manolo Torres de su novia, después de mostrarle una fotografía de ella:

El aviador cogió un retrato que estaba encima del mantel al lado de las tazas de café. Le dijo a Manolo:

-Bueno, entonces qué. ¿Quedamos en que te gusta?

-Es una monada, chico, desde luego. Le doy diez.

-Y sobre todo mira, lo más importante, que es una cría. Ya ves, dieciséis años no cumplidos. Más ingenua que un grillo. Qué novio va a haber tenido antes ni qué nada. ¿No te parece?, es una garantía. Ya de meterte en estos líos tiene que ser con una chica así. Para pasar el rato vale cualquiera, pero casarse es otro cantar (Martín Gaite 1991: 48).

En la novela los chicos distinguen de este modo claramente entre aquellas chicas que son para casarse y aquellas otras que son sólo para tener

\footnotetext{
${ }^{3}$ A partir del momento en que se formalizaba el noviazgo y el novio entraba en casa de la novia, "la coacción de la familia se hacía progresivamente abrumadora e inesquivable. Y cuanto mejor se viera tratado el recién admitido a aquellas habitaciones donde se servían meriendas, se oía la radio, se dilucidaban cuestiones económicas y se hacía crochet, más prisionero se sentía. También podía sentirse prisionera ella, claro está, pero la conformidad que le habían predicado desde la infancia le impedía ahondar en aquella vaga insatisfacción experimentada a veces al comprobar que su novio seguía siendo para ella un perfecto desconocido, al que se acepta y se perdona a ciegas" (Martín Gaite 1992a: 208).
} 
una aventura. Las primeras tienen que ser jóvenes, guapas, inocentes y vírgenes - lo que se entendía entonces por una "chica decente". Los chicos, en cambio, han de ser mayores que ellas, tener experiencia con las mujeres, y no tienen por qué cumplir el requisito de fidelidad. El mismo Ángel no le es fiel a Gertru durante su noviazgo. Los amigos de él lo saben, pero, lejos de reprobar su conducta, llegan incluso a admirarle por ello, dado su éxito con las mujeres. Esto pone de manifiesto la doble moral característica del nacionalcatolicismo, que imponía obligaciones muy distintas a mujeres y hombres, mucho más rígidas a las mujeres, siendo más tolerante con las transgresiones a la norma por parte de los varones — así, por ejemplo, "casas de tolerancia" era significativamente uno de los términos con el que se designaba durante el franquismo a los prostíbulos donde los clientes eran generalmente de sexo masculino.

Como se comentó anteriormente, Julia, la hermana de Natalia en la novela de Martín Gaite, sufre porque su novio Miguel vive en Madrid y quiere que vaya a verle, pero la familia de Julia se opone. A la familia de Julia no le gusta demasiado Miguel porque no es de "familia conocida" y además no es lo que se entiende por "un buen partido"; por ejemplo no es demasiado convencional en cuanto a su trabajo como guionista de cine. Julia está muy disgustada, incapaz de "dar gusto" a la vez a la familia y al novio, por lo que se pasa la novela con dolor de cabeza y llorando - reacciones por otra parte muy frecuentes en todas las chicas que aparecen en la novela, así como que digan que "tienen prisa", que "se les hace tarde" (no se sabe muy bien para hacer qué). Julia se siente además culpable por la "voluptuosidad" que siente hacia su novio, sobre todo cuando recuerda algunos de los momentos íntimos que vivieron juntos. Sin embargo, se ve obligada a decirle a Miguel que no le parece bien y a enfadarse con él, aunque no lo sienta verdaderamente así. Un día, Julia le escribe una carta a su novio en la que le dice cosas como las que él le escribe, pero al día siguiente se arrepiente y se va a confesar, contándole al cura el tema de la carta: "Anoche me desperté y estuve escribiéndole cosas como las que me escribe él, diciéndole que me acordaba mucho de todo lo de ese año cuando nos hicimos novios, que es mentira cuando le digo que me enfado por las cosas que me dice él en las cartas..." (Ibid.: 83). El confesor le contesta que lo importante es que salga victoriosa de las tentaciones, que "Dios ha tenido misericordia de ti y te ha dado siempre fuerza para perseverar en el camino de la virtud" (Ibid.), y que aunque Miguel le diga a Julia que es una "ñoña", en el fondo aprecia su comportamiento "virtuoso": "—Sí lo aprecia, hija mía. En el fondo de su alma lo aprecia. La pureza es el adorno más fragante del alma de una joven y su blancura llega a los sentidos de todos los hombres" (Ibid. 84). Julia le comenta al cura que se acuerda so- 
bre todo de su novio cuando va a ver alguna película, por lo que el cura le recomienda que no frecuente el cine, porque éste "siempre hace algún mal" (Ibid.): "El cine, siempre el cine, cuántas veces lo mismo. Ahí está el mal consejero, ese dulce veneno que os mata a todas" (Ibid. 82-83).

Otro de los personajes destacados en Entre visillos es Elvira, otra "chica rara" de acuerdo con la denominación de Martín Gaite, que no se ajusta con facilidad a los modelos femeninos propugnados por la moral del nacionalcatolicismo. Se trata de la hija del director del Instituto, quien, a diferencia de la mayoría de las chicas de su entorno, lee, pinta, va a pasear sola, etc. Como a Natalia, a Elvira también le aburren bastante los temas de conversación de las demás chicas. Su padre acaba de morir, y Elvira se ve obligada a respetar las convenciones sociales que implica el luto - entre otras, vestir de negro, estar triste, no poder salir e ir al cine o al Casino con las amigas-: "Elvira se levantó a echar las persianas y se acordó de que estaría por lo menos año y medio sin ir al cine. Para marzo del año que viene, no. Para el otro marzo. Eran plazos consabidos, marcados automáticamente con anticipación y exactitud, como si se tratase del vencimiento de una letra. Con las medias grises, la primera película. A eso se llamaba el alivio de luto" (Ibid. 114). Elvira tiene que quedarse en casa con su madre, que se esfuerza en que todo recuerde que la familia está de luto, dada la importancia que tiene el "guardar las apariencias" y "el qué dirán" en este contexto social: "A la madre le gustaba que estuvieran los balcones cerrados, que se notara al entrar de la calle aquel aire sofocante y artificial. "Es una casa de luto" — había dicho. Elvira se asomó al balcón y respiró con fuerza” (Ibid. 122).

Elvira se aburre con las visitas que van a su casa y acepta a regañadientes ciertas convenciones sociales. Cuando le visita su amigo Emilio, que está enamorado de ella, hablan asomados a la ventana y él le pregunta:

—¿Qué piensas? ¿Estás triste?

-Ni siquiera. Embobada. Me aburro, ¡si vieras cómo me aburro!

-Pero, ¿por qué? ¿qué piensas?

—Nada. ¿No te digo que nada? No es vivir, vivir así.

Miraba la calle.

- Si te molesto, me voy —dijo Emilio, después de un poco.

Ella le miró. Era como un perro dócil Emilio, con los mismos ojos de la infancia. A veces le conmovía [...]

—Di algo, hombre. Cuéntame algo. A ver si te voy a contagiar mi spleen. ¿Qué haces, escribes?

—Algo. Vámonos dentro. Hace frío.

-Yo no tengo frío, ¿tienes frío?

—No, lo decía por ti. Pero además no está bien que estemos aquí asomados, Elvira, puede pasar alguien.

Ella se soltó y le buscó la mirada. 
- ¿Y qué pasa, di, qué pasa? A ver si por estar de luto ni siquiera voy a poder hablar contigo en el balcón, ¿̇es que estamos haciendo algo malo? Pareces mi madre (Ibid. 124-125).

Como se señaló anteriormente, el Casino constituye en esta novela el principal centro de reunión de los jóvenes burgueses. Las chicas andan preocupadas porque no les quiten a los chicos ni "las nuevas", las chicas más jóvenes que comienzan a ir al Casino, ni "las de afuera", las chicas que van a Salamanca sólo durante las fiestas, les quiten los chicos. Estas últimas normalmente son chicas que vienen de la capital, como Marisol, más atrevidas y desenvueltas, no tan condicionadas por las convenciones sociales como las que viven allí durante todo el año, por lo cual son más libres de hacer lo que quieren y les "levantan" muchas veces a los chicos por los que las chicas de provincias han estado suspirando durante todo el año; este es por ejemplo el caso de Goyita, a quien Marisol le ha "pisado" a Manolo Torres, el chico del que Goyita está enamorada y al que había estado persiguiendo durante meses. Este año las chicas están también preocupadas porque en el Casino está habiendo mucha "mezcla", término con el que se refieren al hecho de que lo frecuenten chicas de clase más humilde, y que recuerda a los conceptos de contaminación, pureza y peligro de los que habla Mary Douglas (1991):

- ¿Vas a ir al Casino a la noche?

- Creo yo que daremos una vuelta. ¿Tú qué dices, Julia?

-A mí me da igual. Total, está siempre tan ful.

—Sí, es verdad, no sé qué pasa este año en el Casino. Y cuidado que la orquesta es buena, pero no sé.

—La mezcla — saltó Mercedes con saña- La mezcla que hay. Decíamos de la niña del wolfram. La niña del wolfram, la duquesa de Roquefeler, al lado de las cosas que se han visto este año. Hasta la del Toronto, ¿para qué decir más?, si hasta la del Toronto se ha vestido de tul rosa. Y por las mañanas en el puesto. Así que claro, es un tufo a pescadilla...

-No, y que hay demasiadas niñas, y muchas de fuera. Pero sobre todo las nuevas, que vienen pegando, no te dejan un chico. (Martín Gaite 1991: 22-23).

Por la misma razón, en esta novela los padres de las familias burguesas prefieren mandar a sus hijas a los colegios privados religiosos, pues consideran que en los institutos hay mucha "mezcla". Así se lo explica Salvador —el bedel del Instituto- a Pablo Klein: "Por lo visto, las chicas de familias conocidas lo corriente, cuando hacían el bachillerato, era que lo hicieran en colegios de monjas, donde enseñaban más religión y buenas maneras, y no había tanta mezcla. "¿Pero mezcla de qué? - le pregunté a Don Salvador", "Mezcla de chicas humildes. La matrícula del Instituto es más barata que en un colegio y vienen muchas chicas de pueblos, ya lo habrá notado. 
No es de buen tono estudiar aquí" (Ibid. 213). Elvira y Natalia han sido una excepción en este sentido, pues las dos proceden de familias burguesas y han ido sin embargo al Instituto. Pero en la familia de Natalia se preocupan cuando ésta comienza a tener amigas de condición más humilde, como Alicia; se arrepienten entonces de haberla mandado al Instituto y tratan de buscarle otras amistades que consideran más adecuadas: "Desde que viene Alicia —escribe Natalia en su diario_- han vuelto a hablar varias veces en las comidas de lo conveniente que habría sido que yo este año no me hubiera matriculado en el Instituto. Dicen que mientras estaba Gertru, menos mal, pero que ahora he perdido todo contacto con la gente educada" (Ibid.: 222).

Pero esta vida apacible y convencional de estos jóvenes burgueses de provincias, con sus intereses y preocupaciones características, se desestabiliza de algún modo con la llegada a la ciudad de Pablo Klein, cuya presencia afectará de forma más o menos directa a las vidas de los distintos personajes. Por su condición de extranjero e individuo poco convencional, este personaje es observado y vigilado desde el mismo momento de su aparición por todos, tanto por las chicas como por los chicos. Pablo Klein llega a la ciudad en tren, después de un viaje interminable y tras varias averías en las que se tienen que detener durante un tiempo. Durante el viaje, Pablo se dedica a observar a la gente, cómo hablan y cómo se comportan los viajeros, lo mismo que hará luego en la ciudad en relación a sus habitantes. Su mirada diferente proporciona un buen ángulo desde el que observar la vida de esta ciudad de provincias, a través de lo que él ve y de las relaciones que va estableciendo con los distintos personajes. Al llegar a la estación de tren, nadie lo está esperando - como también le ocurre a Andrea, protagonista de Nada de Laforet, a su llegada a Barcelona al comienzo de esta novela. Se dirige entonces al Instituto para hablar con el director, Rafael Domínguez, el amigo de su padre que le ha contratado para dar clases, y allí se entera de que ha muerto hace tan sólo unos días. Pablo describe del siguiente modo el Instituto en el que posteriormente impartirá clase —que se ubica en el mismo lugar y presenta las mismas características generales que aquel en el que estudió la autora de la novela (Cf. Martín Gaite 1980):

Franqueé [la puerta] y entré en un patio grande y absolutamente desnudo, como el alma de una cárcel. Al fondo, a unos cien metros, estaba la fachada del Instituto. Era de piedra gris, sin ningún letrero ni adorno, y tenía solamente tres ventanales uno encima de otro y encima, a su vez, de una puerta demasiado pequeña hacia la cual iba avanzando. Todo estaba arrinconado en la parte de la izquierda, de tal manera que por el otro lado sobraba mucha pared. Chocaba la desproporción y la torpeza de aquella fachada que parecía dibujada por la mano de un niño. No había nadie. Graznaban en el tejado unos pájaros negros. (Martín Gaite 1991: 34). 
Pablo no sabe muy bien qué hacer al enterarse de la noticia de la muerte del director. Se aloja de forma provisional en una pensión cerca del Instituto, y los primeros días se dedica a pasear por la ciudad y a observar a la gente, sentado en las terrazas. Ese sentimiento de provisionalidad le acompañará durante toda su estancia en la ciudad, como él mismo declara. No tiene un propósito muy definido, no sabe si irse o quedarse en Salamanca, pero al final decide ir a la casa del director del Instituto por la curiosidad que siente en conocer a su familia. El proyecto de dar clases de alemán en el Instituto es en el fondo para Pablo una excusa para pasar un tiempo en esta ciudad, pues el verdadero motivo de su estancia es "volver a mirar con ojos completamente distintos la ciudad en la que había vivido de niño, y pasearme otra vez por sus calles, que sólo fragmentariamente recordaba" (Ibid.: 51).

Cuando Pablo Klein llega a casa del director recién fallecido, la casa se encuentra llena de gente que ha ido a visitar a la familia a dar el pésame. Allí Pablo conoce a la mujer y a los dos hijos del director, Elvira y Teo. Pablo entra en la casa del director al mismo tiempo que otras señoras, y se encuentra de repente rodeado de gente que no conoce; se siente como si estuviese dentro de un teatro, en medio de una escena teatral en la que no sabe muy bien cuál es su papel. Cuando está a punto de irse, se encuentra con Elvira, que lo reconoce porque justo la noche anterior había estado mirando una foto en la que aparecía Pablo con su padre en Suiza. En esta primera conversación, Elvira le cuenta que la pasada noche soñó que su padre vivía todavía y que los tres eran amigos:

Me contó que había estado a punto de ir a Suiza con su padre y que la noche anterior se desesperaba asomada al balcón de su cuarto pensando que eso ya nunca se podría remediar, que las cosas que podía haber hecho en aquel viaje ya nunca las haría y la gente que podría haber conocido ya no la conocería; y que pensando eso no se podía consolar. Que un viaje le puede cambiar a uno la vida, hacérsela ver de otra manera y a ella ese año se la habría cambiado. Le pregunté que por qué no había ido, pero no me contestó directamente.

—Si usted no vive aquí — dijo-, no puede entender ciertas cosas. Hace poco que está aquí, ¿no?

-Tres días.

- Tres días - repitió- No puede entender nada. Si le explico por qué no fui a Suiza se reirá, dirá que qué disparate, que eso no puede ser. Creerá que lo ha entendido, pero no habrá entendido nada. Solamente uno que vive aquí metido puede llegar a resignarse con las cosas que pasan aquí, y hasta puede llegar a creer que vive y que respira. ¡Pero yo no! Yo me ahogo, yo no me resigno, yo me desespero.

Hablaba con rabia, con voz excitada, como si yo la estuviera contradiciendo [...] -Aquí tendría que estar usted diez días de la mañana a la noche, aquí en esta casa, a ver si se ahogaba o no se ahogaba, como yo me ahogo. Oyendo cómo le 
dicen a uno de la mañana a la noche pobrecilla, pobre, pobrecilla. Día y noche, sin tregua, día y noche. Y venga suspiros y de compasión y más compasión, para que no se pueda uno escapar. Y compasión también para el muerto, compasión a toneladas para todos, todos enterrados, el muerto y los vivos y todos. Usted ¿qué cree?, ¿que un muerto necesita tanta compasión?, ¿que necesita de los vivos para algo? Por lo menos a él, que le dejen en paz, ¿no le parece? [...] Y se echó a llorar con violentos sollozos (Ibid: :54-56).

Pablo conoce también ese día en casa de Elvira a Emilio, quien encontrará en Pablo el confidente que busca para contarle sus sentimientos de amor hacia Elvira y su desesperación por no saber si ella le corresponde, puesto que unas veces le hace caso pero otras no ${ }^{4}$. Emilio y Elvira se conocen desde la infancia; el año anterior habían estado más tiempo juntos y la gente decía que eran novios. Pero Elvira asegura que ella no quiere tener novio (o al menos que se enteren los demás), por lo que le dice a Emilio ante la insistencia de éste: “'Tú sabes lo que es pasarse a lo mejor tres años de novios formales, con la gente pendiente de si nos cogemos las manitas o nos las dejamos de coger? Anda, no" (Ibid.: 198).

Pocos días después de conocer a Elvira, Pablo recibe una carta de ella donde le habla de sus sentimientos y de lo especial que fue su encuentro: "La carta, dentro del tono intencionadamente poético y confuso, era casi una declaración de amor" (Ibid.: 95). Pablo se siente entonces desconcertado, no sabe qué responder y opta finalmente por pensar que la carta bien podría haberse perdido y por tanto él no la habría llegado nunca a recibir, por lo que no estaría obligado a responder: "Me pareció una solución maravillosa. "Se ha perdido —decidí-. Como si se hubiera perdido". Y me alegré" (Ibid.). El personaje de Pablo se desmarca así de la seguridad y aplomo que suele acompañar a los héroes de "novelas rosa" de la época, que saben en todo momento lo que quieren y cuáles son los medios más idóneos para conseguirlo. Por el contrario, la timidez e indecisión de Pablo le convierten más bien en un "antihéroe", al igual que el personaje de Emilio, lo que lleva también a poner en cuestión el modelo de masculinidad monolítico del nacionalcatolicismo y su apertura hacia otros arquetipos masculinos, más acordes con la realidad y su diversidad característica.

\footnotetext{
${ }^{4}$ Pablo se convertirá asimismo en confidente de otros personajes de la novela - como Elvira, Natalia o también Rosa, la animadora del Casino con la que coincide en la pensión-, precisamente, como le explica Emilio, por su carácter de extranjero, de estar de alguna manera fuera de los convencionalismos y prejuicios que atan y condicionan a los demás personajes: "Tú podrías ayudarme mucho — le confiesa Emilio- Y Yo contigo hablo mejor que con nadie. Precisamente porque eres neutral, porque se sabe seguro que no vas a comentarlo con otras personas. Yo lo sabía, desde que te conocí, que te iba a buscar cuando te necesitara, tienes una inteligencia distinta a la de los demás" (Ibid: 199).
} 
Por otra parte, Pablo conoce en la pensión a Rosa, la animadora que canta en el Casino. Es la única chica con la que Pablo tendrá una amistad y se sentirá cómodo, sobre todo, por la sinceridad que no encuentra en las otras chicas. Rosa es, según la descripción de Pablo, una mujer de unos treinta y cinco años, pálida, de rostro vulgar, con uñas afiladas pintadas de rojo y grandes pendientes de bisutería. Ella se aloja en la misma pensión y un día invita a Pablo a que se siente a comer en su mesa. Nada más hacerlo, Pablo se da cuenta de que todos les miran: "Habían entrado otras personas en el comedor y nos miraban. Yo me empecé a encontrar a disgusto y se lo dije a ella. "Que nos miran, ¿verdad?", dijo en voz alta y destemplada, "No, si no me extraña. Aquí la animadora, lagarto, lagarto, y los que van con ella igual, cosa perdida. Anda, vámonos, que miren a su padre," (Ibid.: 79).

Pablo irá por primera vez al Casino para oír cantar a Rosa ${ }^{5}$. Nadie verá con buenos ojos la relación de amistad entre ambos. "Gente de esa no queremos" (Ibid.: 105), le advierte a Pablo una chica en el Casino, refiriéndose a la animadora. "Te creerás que somos todas como tu amiga" (Ibid.: 103), le dice furiosa a Pablo otra chica a la que ha sacado a bailar. Las amigas le cuentan a Elvira la relación de Pablo con Rosa, y Elvira se muestra desconcertada:

Elvira se quedó pensativa.

—Qué raro —dijo luego-. No le pega nada. ¿Y ella qué tal es?

—Mona, pero va demasiado exagerada. Bueno, es lo suyo...Y además ya mayor. Al lado de él, vulgarita.

—Él desde luego está de miedo — dijo Goyita—. ¿Es extranjero, no? Se le nota un acento especial.

\footnotetext{
${ }^{5}$ La primera impresión que le produce a Pablo el Casino pone en evidencia la intensa vigilancia y control social al que en la novela se encuentra sometido cada individuo por el entorno social que le rodea: "Tenía yo la idea de sentarme en un rincón apartado y tomarme un refresco tranquilamente mientras escuchaba a Rosa y esperaba que terminase su trabajo, pero de la primera cosa que me di cuenta al entrar, fue de que no existía ningún lugar apartado, sino que todos estaban ligados entre sí por secretos lazos, al descubierto de una ronda de ojos felinos. Muchachas esparcidas registraron mi entrada y siguieron el rumbo de mi indecisa mirada alrededor. No tocaba la música y no vi a Rosa. Había mesas por todas partes, totalmente ocupadas, un silencio ondulado de cuchicheos y redondeles de luz en el centro de la pista vacía. Comprendí que tenía que andar en cualquier dirección afectando desenvoltura. Vasos, botellas, adornos, largas faldas pálidas fueron quedando atrás en una habitación amarilla. Al fondo había una puerta con cortinas recogidas. La traspuse: era el bar. Me asaltó un rumor de voces masculinas. No habría más de tres mujeres entre los hombres que fumaban en grupos ocultando el mostrador, y una de ellas era Rosa, en el centro de un corro de chicos vestidos de etiqueta" (Ibid.: 98).
} 
Isabel no le había visto nunca, dijo que a ver si se lo enseñaban. Le preguntaron a Elvira que a qué había venido, estaban todas pendientes de su contestación. Ella dijo que no sabía nada, que apenas le conocía, que por qué le preguntaban a ella.

—Está por él que se mata —resumió Isabel cuando salieron-. Ya veis lo nerviosa que se pone en cuanto le preguntamos cosas. No suelta prenda, se ve que quiere tener la exclusiva.

-Sí; pero como presume de que no le gustan los chicos. Como un ser superior (Ibid: 115-116).

Rosa se marcha de Salamanca al terminar su contrato a finales de septiembre. Pablo, por costumbre, sigue yendo al Casino. Allí comenzará a frecuentar el grupo de Emilio: "Me incluían en su círculo de noticias y chismes, esperando que en mí despertaran el mismo interés que tenían para ellos" (Ibid: 131). A través de Emilio, Pablo conoce a Yoni, un joven escultor al que todo el grupo admira - "hablaban de este chico como de un semidiós" (Ibid.: 132) — porque lo ven moderno, libre, sin prejuicios, muy selectivo con sus amistades, por haber viajado a otros países, y también por las famosas fiestas que se celebran en su estudio, ubicado en el ático del Gran Hotel de Salamanca. En realidad, como se entera luego Pablo, el padre de Yoni, dueño del hotel, es quien paga el estudio y todos los lujos de su hijo, quien sin embargo "hablaba de él con desprecio absoluto y lo llamaba viejo cerdo" (Ibid.: 133-134). En el estudio de Yoni, Pablo vuelve a oír hablar de Elvira: "Me enteré de que pintaba y de que Yoni la admiraba mucho por su falta de prejuicios [...] Le dijo Yoni que era una de las pocas chicas iguales a un amigo [...] Durante este tiempo yo pensaba mucho en Elvira y deseaba volver a verla" (Ibid:: 134).

Pablo se encuentra por fin de modo casual con Elvira un día que va paseando cerca del río. Ella está sola, sentada leyendo un libro. Pablo está un poco bebido y se atreve a sentarse a su lado y a hablar con ella. Ella le confiesa: "Me gustaría irme lejos, hacer un viaje largo que durase mucho. Escapar”; “Escapar de qué?»; "De todo —dijo; y suspiró”" (Ibid.: 136). Luego Elvira le lee emocionada una poesía de Juan Ramón Jiménez con la que se siente muy identificada: "Mis raíces, qué hondas en la tierra, / mis alas, qué altas en el cielo, / y qué dolor de corazón distendido". Elvira explica a Pablo el significado que tiene para ella el poema: "Yo, por ejemplo, hoy aquí, lejos de la gente y de las circunstancias que me atan, me olvido del cuerpo, no me pesa, sería capaz de volar; pero en cuanto me ponga de pie y eche a andar hacia casa se me vendrá todo el recuerdo de mi limitación, eso quiero decir, ¿lo entiende?" (Ibid.: 137). Ella quiere saber lo que él piensa de ella, si la considera tan especial como los otros chicos. Elvira le pregunta si le parece ridícula - le confiesa que siempre se siente ridícula con él-y 
Pablo, mientras piensa que lo único que le apetecería sería besarla, le contesta que no, que no le parece ridícula, pero que tiene el vicio de darle muchas vueltas a las cosas, y también de querer parecer original:

Se quedó abatida y silenciosa. Luego de golpe se puso a hablarme de su carta, a justificarse de haberla escrito, a llamarse ridícula a sí misma; y de vez en cuando me miraba como esperando a que la contradijese [...]

-Dejemos esto, por favor. Es inútil intentar hacerse entender de los demás. Una vez más me doy cuenta. Le pido perdón por haberle aburrido con semejante carta y con las explicaciones de ahora. Soy imbécil.

— ¿Imbécil por qué?

—Porque sí. Le advierto que soy yo la primera que se ríe de sí misma — dijo en un tono altivo y agresivo-. De mi histerismo, si usted quiere llamarlo así.

-Yo no quiero llamarlo nada.

—Bueno, pues otros lo han dicho. Lo sé. Me complico la vida, me hago preguntas y me meto en líos. Digo lo que pienso y lo que siento; no tengo miedo de lo que piensen de mí. Y estoy contenta, a pesar de todo, siendo como soy (Ibid.: 138-139).

Al día siguiente, Pablo va a ver a Elvira a su casa. Se disculpa por si ha estado insolente el día anterior, pero ella le dice que no, que sus comentarios le han hecho mucho bien:

Me dijo que se alegraba de mi amistad, que esperaba merecerla, que precisamente necesitaba mucho de personas como yo que dicen siempre la verdad. Que nadie le había dicho de sí misma cosas como las que yo le había dicho la tarde anterior.

- Pero si yo no te dije nada de particular.

- Sí, que pienso demasiado en mí misma. Y es verdad: que me doy vueltas y me creo original. Algo así. Me sentó muy mal, te lo confieso, pero hiciste bien en decirlo, fuiste como nadie, son cosas que nadie dice.

Me explicó que en general la gente la admiraba. Que los chicos, sobre todo, la admiraban.

-No me creas fatua por esto, pero es verdad. Tengo bastantes amigos, y entre unos y otros me han hecho pensar que valgo algo más que otras chicas, porque soy así, impulsiva, ya lo ves tú mismo; porque leo y tengo inquietudes que otras chicas de aquí no suelen tener. Ellas me ponen verde, te lo puedes figurar, porque tengo amigos y salgo y voy a los sitios, lo que se puede en un sitio como éste. Porque con las chicas me aburro, lo lógico (Ibid.: 141-142).

Esa misma tarde estando en casa de Elvira, Pablo de repente la besa y ella se pone de pie rápidamente porque oye que viene alguien. Antes de despedirse de Pablo, Elvira le dice que se pensará que es una "fresca", que no quería que aquello pasase. Pablo le contesta que la ha besado porque le había parecido que ella lo deseaba. Elvira entonces se enfada y le dice que es un fatuo y un grosero, le pide que se vaya y que no le diga a nadie 
que ha estado en su casa. Después de este suceso, Pablo decide que será mejor no volver a verla.

Entretanto, comienzan las clases en el Instituto. Natalia tiene como profesor de alemán a Pablo Klein. Un día al salir de clase, se lo encuentra y habla con él:

Dijo que le gustan las clases como la que hemos dado hoy, con pocas alumnas, pero que le extraña el poco interés que tienen las chicas de todos los cursos, y más todavía que las que faltan le pongan pretextos de enfermas, habiendo advertido él desde el primer día que piensa dar aprobado general y no poner faltas de asistencia. Por lo visto siempre lo ha hecho así [...] Al salir de la tienda me hizo la primera pregunta directa, que qué carrera pensaba hacer cuando acabase el bachillerato. Le dije que no sabía, que ni siquiera sabía si iba a hacer carrera.

— ¿Cómo? ¿Estamos en séptimo y todavía no lo sabe?

Le expliqué que dependía de mi padre, que le gustaba poco.

- ¿Qué es lo que le gusta poco?

- Los estudios en general, no sé; que esté todo el día fuera de casa. Como soy la más pequeña.

— ¿Y qué que sea usted la más pequeña? ¿Qué relación tiene?

- Como las otras hermanas no han estudiado carrera.

-Porque no habrán querido. ¿O les gustaba?

-No sé.

Me siguió preguntando cosas, y lo de papá no lo entendía, aunque la verdad es que tampoco lo entiendo yo. Pero él menos todavía, claro, porque no conoce a papá y no ha oído las conversaciones que se tienen en boca y las críticas que se hacen, y eso. Le dije que de estudiar me gustaría ciencias naturales, todo lo que trata de bichos y flores y cosas de la Naturaleza. Creo que hay una carrera de esto, aunque no estoy muy cierta, porque sólo con Gertru lo he hablado alguna vez. Se quedó muy pasmado de que, queriendo yo, admitiera la duda de estudiar carrera o dejarla de estudiar. Dijo que era absurdo.

- ¿Pero usted ha tratado de convencer a su padre, ha insistido?

-No, no mucho todavía. Lo malo de esa carrera es que me parece que tendría que irme a Madrid.

—¿Y qué? ¿No le gustaría?

—Sí, claro que me gustaría (Ibid:: 185-187).

Natalia encuentra en Pablo Klein un interlocutor válido para compartir sus inquietudes e intereses, que no halla en las demás personas de su entorno ("me chocaba - escribe Natalia en su diario- que estas cosas estuviera tratando de explicárselas a un desconocido. Claro que no me parecía un desconocido. Me miraba atentamente y completaba alguna de mis frases, animándome a seguir" (Ibid.: 187). Salvo excepciones, a las muchachas de la época no se las animaba a estudiar, y menos a seguir estudios superiores. Como indica I. de la Fuente, había una frase muy repetida por las madres en este sentido: "Mujer que sabe latín no tiene buen 
fin" ${ }^{\circ}$. En su estudio sobre los usos amorosos de la posguerra española, C. Martín Gaite señala que en la sociedad de posguerra "se recomendaba la prudencia en el estudio, como si se tratara de una droga peligrosa que hay que dosificar atentamente y siempre bajo prescripción facultativa. A los primeros síntomas de que empezaba a hacer daño, lo aconsejable era abandonarla" (Martín Gaite 1992a: 68), ya que, como se afirmaba en una revista de la época, "en las mujeres el conocimiento analítico puede perturbar las finas arterias de su feminidad" 7 . De este modo, los agentes socializadores del nacionalcatolicismo trataban de cortar las alas a las chicas que querían estudiar, argumentando que el conocimiento pertenecía en exclusividad a la "naturaleza masculina" - $\mathrm{y}$, por tanto, la falta de conocimiento o ignorancia es lo propio de la femenina, aunque esto último solía decirse más sutilmente y rodeado por lo general de elogios a la delicadeza y a la gracia, también supuestamente características de la feminidad. Martín Gaite señala a este respecto que "de forma bien tajante lo había establecido Pilar Primo de Rivera en su catecismo particular. A las que pretendieran surcar los aires del saber con vuelo tan seguro y ambicioso como el del varón convenía cortarles las alas: "Las mujeres nunca descubren nada: les falta desde luego el talento creador, reservado por Dios para inteligencias varoniles; nosotras no podemos hacer nada más que interpretar mejor o peor lo que los hombres han hecho"" (Primo de Rivera 1943. Cit. en Martín Gaite 1992a: 68). Como muestra Martín Gaite, opiniones similares aparecen en las revistas de ese período:

No nos parece mal este avatar que transforma a la inútil damisela encorsetada en compañera de investigación. Pero a nadie más que a ella es necesario un freno protector que la detenga en el momento en que una desaforada pasión por el estudio comience a restar a su feminidad magníficos encantos...Nos asusta tanto para mujer propia o simplemente amiga leal la mujer que calla sin atreverse a formular controversia como aquella otra que sabe tanto como nosotros y no nos mira con admiración cuando le explicamos un tema de mecánica o geopolítica.

\footnotetext{
${ }^{6}$ Martín Gaite (1982. Cit en De la Fuente 2002: 116). De la Fuente señala que en el lento despertar de los años cincuenta en España, "el matrimonio seguía siendo "la principal carrera de la mujer" y ahí concentraban ellas sus sueños - los únicos que no estaban prohibidos-, pero estudiar ya no era incompatible. "Mujer que sabe latín no tiene buen fin", repetían muchas madres todavía, temerosas de que una identificación excesiva con los libros hiciera a sus hijas menos femeninas, es decir, menos deseables, menos aptas para su gran misión. Más vulnerables. Existía el temor latente a la mujer sabihonda, con veleidades intelectuales, curiosa. Pero las más avispadas pensaban que si estudiaban serían más fuertes. "Hasta para coser un botón viene bien estudiar", contestaba la madre de Carmen Martín Gaite a sus amigas cuando le ponían en guardia sobre la afición al estudio de su hija" (Ibid.).
}

7 Medina, 15 de noviembre de 1942. (Cit. en Martín Gaite 1992a: 159). 
Y, puestos a elegir, preferimos a aquella callada y silenciosa, que nos considera maestros de su vida y acepta el consejo y la lección con la humildad de quien se sabe inferior en talento 8 .

Tampoco Ángel, el novio de Gertru, desea que esta última continúe estudiando. Después de estar hablando en una fiesta en casa de Yoni con Pablo Klein, Gertru trata de convencer a su novio para seguir estudiando y terminar así el bachillerato:

-Oye, dice ese chico que por qué no termino el bachillerato — dijo ella de pronto, mirándole en el espejo.

—¿Qué chico?

-Ese profesor.

— ¿Y a él que le importa?

-No, hombre, yo digo también lo mismo. Es una pena, total un curso que me falta. Estoy a tiempo de matricularme todavía.

Habían echado a andar otra vez. Ángel se puso serio.

-Mira, Gertru, eso ya lo hemos discutido muchas veces. No tenemos que volverlo a discutir.

—No sé por qué.

- Pues porque no. Está dicho. Para casarte conmigo, no necesitas saber latín ni geometría; conque sepas ser una mujer de tu casa, basta y sobra. Además, nos vamos a casar en seguida.

Anduvieron un poco en silencio.

-Cuántas veces tenemos que volver a lo mismo. Ya estabas convencida tú también.

-Convencida no estaba - dijo Gertru con los ojos hacia el suelo.

-Bueno, pues lo mismo da. Te he dicho que lo que más me molesta de una mujer es que sea testaruda, te lo he dicho. No lo resisto.

Llegaron al portal de casa de ella. En el portal él le besó los ojos y le dijo que estaba muy guapa, que quitara el ceño, todo casi al oído. Ella se desprendió.

-Bueno, me subo.

- No, no te subas. Todavía no me has contado cómo era esa cocina que has ido a ver.

-Muy bonita.

-Dilo con una sonrisa, sin esa cara.

- Muy bonita, preciosa, mañana te la dibujo.

- Si te gusta igual, la ponemos igual.

—Es imposible igual — dijo Gertru con los ojos animados repentinamente-. Debe ser carísima. Parece de revista, de esas que vienen con los postres pintados en colores[...]

-Y qué que sea cara. Mi madre nos la regala, no se va a arruinar por eso, que tiene mucho. Pero tú, a ver si aprendes a hacer cosas ricas, que yo soy muy goloso. Si no, no hay cocina.

Se volvió al Hotel silbando (Martín Gaite 1991: 173-175).

${ }^{8}$ Medina, 9 de mayo de 1943. (Cit. en Martín Gaite 1992a: 68). 
De este modo, al sacar el tema de la cocina, Ángel distrae a Gertru de sus deseos por estudiar, al tiempo que le indica sutilmente cuál es su verdadero sitio: la cocina, el espacio doméstico. Gertru se siente emocionada ante la posibilidad de tener una cocina carísima y a la última moda, como las que salen en las revistas, y olvida cualquier otro proyecto, como el de continuar sus estudios, deslumbrada ahora por el brillo de su futura jaula de oro. Por lo demás, después de esta conversación con Gertru, Ángel se vuelve al estudio de Yoni para ligar con una chica francesa a quien había estado acariciando durante la fiesta.

Algunos días más tarde, después de la clase de alemán, Natalia se queda hablando con Pablo Klein y se van a tomar un café. Natalia le habla de su familia, y le explica que antes, cuando vivía con su padre en el campo, todo era distinto, pues ella se llevaba bien con él y eran felices. Sin embargo, desde que él se hizo rico con las minas de wolfram y se habían venido a vivir todos juntos a Salamanca, todo había cambiado: "Desde entonces, la tía era la que mandaba en todos y se había empeñado en civilizarla a ella y en refinar a su padre, que ahora era un señor muy engreído por ser rico" (Ibid::128). Natalia le cuenta a Pablo que ahora su mayor preocupación, por encima de su carrera, es tratar de convencer a su padre para que permita a su hermana Julia irse a Madrid para estar con su novio, y "eso importa más que lo mío" (Ibid::128). Pero Pablo le advierte que se preocupe de sí misma, que ella "era la más joven de la casa y seguramente la que importaba más que no se dejara aniquilar por el ambiente de la familia, por sentirse demasiado atada y obligada por el afecto a unos y a otros. Que la sumisión a la familia perjudica muchas veces. Limita. Me escuchaba con los ojos muy abiertos" (Ibid:: 218-219):

—Cuánto hemos hablado — dijo luego, levantándose-. Y todo el rato de mí. Me voy, es muy tarde. Me van a reñir.

-No deje que la riñan — le dije, ya en la calle, con mucha convicción-. No deje que la riñan de ninguna manera. No es tarde; hemos estado hablando de cosas que le interesan, ¿no le parece?

- Sí, pero eso no se lo puedo explicar en casa.

$[\ldots]$

Me fui a buen paso hacia la pensión por las calles vacías, y mirando las ventanas de los edificios, me imaginaba la vida estancada y caliente que se cocía en los interiores (Ibid:: 219).

A Natalia le van haciendo efecto los comentarios que le hace Pablo, y escribe en su diario que cada vez está más decidida a hacer la carrera. Natalia siente que Pablo es la persona que mejor le entiende: "me parecía la persona que tengo más cerca de todo el mundo, el mayor amigo" (Ibid. 231). Natalia le comenta posteriormente en otra ocasión que tenía razón en lo 
que le había advertido acerca de su familia: "Es verdad que en mi casa no se puede vivir [...] tenía usted razón. La familia le come a uno, yo no sé. Hoy sin falta voy a hablar con mi padre" (Id.). Entretanto, Natalia está siendo cada vez más estrechamente vigilada por su entorno familiar, con el objeto de que no sea diferente de las demás chicas y tenga sus mismas preocupaciones, que no estudie sola en la habitación, sino en el salón con las hermanas y su grupo de amigas, etc. Natalia está un poco harta de este control familiar y se propone tratar de pasar lo más desapercibida posible en la casa, del modo que ha descubierto más eficaz:

Procuro pasar lo más inadvertida posible. Me he dado cuenta de una cosa: de que en casa para pasar inadvertida es mejor hacer ruido y hablar y meterse en lo que hablan todos que estar callada sin molestar a nadie. Siempre que me acuerdo canto por los pasillos y tengo cara de buen humor, y he empezado a mirar figurines y a dar opiniones sobre los trajes de las hermanas, y a decir que qué buen sol si veo que está despejado. También he dicho que quiero unos zapatos nuevos. (Ibid: 222-223).

Natalia se decide por fin a hablar con su padre, comentándole "que nos volvemos mayores y él no lo quiere ver, que la tía Concha nos quiere convertir en unas estúpidas, que sólo nos educa para tener un novio rico, y que seamos lo más retrasadas posible en todo, que no sepamos nada ni nos alegremos con nada, encerradas como el buen paño que se vende en el arca y esas cosas que dice ella a cada momento [...] Le he dicho que si tengo que ser una mujer resignada y razonable, prefiero no vivir" (Ibid.: 232233). Pero Natalia comprueba con impotencia que la conversación con su padre no sirve de nada: "Papá — le he dicho—, tú antes no eras así, te vuelves como la tía, te tenemos miedo y nos estás lejos como la tía". Papá estaba muy perplejo [...] y me ha mirado, sin saber qué decir [...] Estaba muy dolido, pero no comprende que yo lo que quiero es ayudarle a ser más sincero, a darse cuenta de lo que tiene alrededor. No he conseguido que nos entendamos, he visto que es imposible y también toda su cobardía" (Ibid:: 233).

Por su parte, Pablo va a visitar un día a la familia de Elvira, y allí se encuentra con ésta, su madre, Teo y Emilio, que están preparando juntos las oposiciones a notarías. Elvira se siente incómoda y ridícula, sobre todo cuando Teo y Emilio la animan a que le enseñe sus cuadros a Pablo. Se muestra reticente y entonces Pablo le dice que pueden interesarle las opiniones de los demás sobre su pintura, preguntándole que si acaso le molesta que le pongan defectos otras personas que no sean ella misma. Ella le contesta agriamente asegurándole que conoce muy bien sus propias limitaciones, tras lo cual se va a llorar de rabia a su habitación, desde donde 
escucha a Pablo charlar animadamente con su familia. Cuando Pablo se va, Elvira le dice a su madre que quiere casarse con Emilio lo antes posible.

Pablo finalmente va perdiendo también la motivación por las clases en el Instituto y se da cuenta de que la ciudad se le está haciendo terriblemente aburrida y que le está ahogando. Siente el Instituto y la ciudad en general tan ajenos como el primer día que llegó a Salamanca:

Hacía todos los días el camino de ida y vuelta del Instituto [...], pero nada de aquello me era familiar; coincidía siempre con la primera imagen que tuve de ello la tarde de mi llegada, cuando hablé con la mujer que fregaba los escalones. Me aburrí de los paseos con las niñas y empecé a pasar lista y a poner faltas de asistencia, porque don Salvador me dijo que no estaban preparadas para tener disciplina de otra manera, que me rogaba que lo hiciera así. Por lo visto mis métodos extrañaban demasiado a todos. También me señaló un libro de texto que debía seguir en adelante (Ibid.: 248).

Al llegar las vacaciones de Navidad, se despide del Instituto y piensa que le "parecía que no dejaba nada en aquellas aulas" (Ibid.: 253. Cursivas mías) — de un modo que recuerda a cómo Andrea, la protagonista de Nada de C. Laforet, al final del relato afirma que se "marchaba ahora sin haber conocido nada de lo que confusamente esperaba [...] De la casa de la calle de Aribau no me llevaba nada" (Laforet 1945: 275).

Antes de abandonar Salamanca, Pablo tiene un último encuentro con Elvira, al coincidir en una exposición de esculturas de Yoni. Elvira y Yoni convencen a Pablo para ir a tomar una copa al estudio de Yoni, pero Pablo no se siente cómodo y, en el momento en que decide irse, Elvira quiere acompañarlo. Al llegar a la pensión donde se aloja Pablo, Elvira insiste en que la deje subir a ver su cuarto. Él le dice que es mejor que no, pero, al insistir ella, Pablo le grita que es una insensata, que no sabe a qué está jugando con él, que si no sabe acaso que si sube a su cuarto no va a volver a salir hasta mañana de madrugada, pero que vale, que suba, y la empuja hacia la escalera. Elvira se enfada entonces con Pablo y le dice que cómo se atreve a tratarla "como una fulana" y hacerle "pasar esta vergüenza”, que si acaso se cree que ella es como la animadora. Entonces Pablo le dice que no, que no es como ella, porque la animadora era directa y sincera, y que si hubiera querido acostarse con él, se lo habría dicho. Él le pide a Elvira que se vaya. Al día siguiente, Pablo se va de la ciudad:

Aquella noche no dormí nada y a la mañana siguiente muy temprano hice mi maleta, pagué la pensión y eché a andar hacia la estación por las calles desiertas, lechosas de una niebla muy fría que desvaía la luz todavía encendida de los faroles. El primer tren para Madrid salía a las ocho de la mañana. Pasé por delante de la casa de Emilio y levanté los ojos a su ventana cerrada. Todavía no sabía bien adónde iría, pero sabía que no iba a volver (Martín Gaite 1991: 258). 
En la estación, Pablo se encuentra con Natalia, que ha ido a despedir a su hermana Julia, pues finalmente se marcha a Madrid. Natalia le cuenta que cada vez está más decidida a estudiar la carrera y él le dice que no se desanime. En la última escena de la novela, Natalia despide a Pablo y a Julia desde el andén de la estación:

El andén estaba casi desierto. Empezaba a levantar un poco el día. Sonó una campana y el tren arrancó.

—Adiós — dijo Natalia, cogiendo la mano que su hermana le tendía.

Yo también saqué la mano y se la di. Empezó a andar un poco con nosotros al paso del tren, siempre mirándonos y sonriendo. Me miraba a mí, sobre todo, los ojos llenos de luz en la cara pequeña, subido el cuello del abrigo.

-Que tenga suerte - - le dije, agitando el brazo.

Ella echó casi a correr, porque el tren iba más de prisa.

-Pero usted vuelve, ¿no? [...]

El tren ya iba a rebasar la pared de la estación. Natalia corría con cara asustada. —Vuelve usted después de las vacaciones, ¿verdad?...A ver si no vuelve — dijo casi gritando.

No le contesté ni que sí ni que no. Seguí diciéndole adiós con la mano, hasta que la vi pararse en el límite del andén, sin dejar de mirarme. Se le caían las lágrimas.

-Adiós, adiós...

Habíamos salido afuera. Sonaban los hierros del tren sobre las vías cruzadas. Con la niebla, no se distinguía la Catedral (Ibid.: 260).

\section{CONCLUSIONES}

Entre visillos refleja bien la moral del nacionalcatolicismo imperante en la España de posguerra en el contexto de una ciudad de provincias - pero que posee validez más allá de ese entorno concreto-, poniendo de relieve el control social constante, la represión sexual en las relaciones entre mujeres y hombres, la relegación de la mujer al ámbito doméstico, la doble moral, etc. La novela pone de manifiesto las enormes dificultades con las que en este contexto se encuentran los individuos, especialmente las mujeres, a la hora de ejercer su libertad y decidir sobre su propia vida.

La buida de la ciudad parece ser la única solución que encuentran Julia y Pablo para salvarse de esa ciudad que les ahoga y poder encontrar así lo que buscan. Es también la esperanza de Natalia. Elvira parece que ha claudicado finalmente de sus deseos, renunciando a ser ella misma, pues accede por el momento a casarse con Emilio, del que no está enamorada; Pablo le atrae, pero no es capaz de tener una relación sincera con él, y además no está dispuesta a asumir que éste la cuestione. La seguridad que le proporciona Emilio, "tan dócil como un perro", como ella misma lo des- 
cribe, es el valor que finalmente parece triunfar en sus elecciones vitales - en este sentido sostiene Marina Mayoral que "la decisión de casarse rápidamente con Emilio parece dictada por el afán de protegerse contra la atracción que siente por Pablo. Se refugia en el amor de un amigo de infancia al que ella puede manipular a su antojo" (Mayoral 2003: XXIX). Elvira renuncia a sus deseos de realización personal, ante el reto de enfrentarse realmente a las normas y atreverse a emprender nuevos caminos más acordes con su manera de ser y fuera de los cánones sociales establecidos, lo que conlleva siempre ciertos riesgos. En realidad, el final queda abierto para Natalia, pues no se sabe si llegará a convencer a su padre para irse a estudiar a Madrid; tampoco se sabe si Elvira se acabará casando con Emilio, ni que ocurrirá con Pablo.

En su papel de extranjero, Pablo ha actuado, de manera casi involuntaria, a modo de factor desestabilizador del equilibrio del sistema: les ha hecho ver a unos y a otros que existen otras alternativas posibles de vida, y que tienen derecho a ellas si así deciden elegirlas — como es por ejemplo el caso de Natalia, a la que el profesor de alemán anima para que se vaya a estudiar a Madrid. El papel de Pablo es por otra parte ambiguo, pues, como se ha visto, su comportamiento no se corresponde con el del típico héroe de novela rosa, que salva a la chica y se casa con ella; sino que se trata más bien de un antihéroe, si bien es cierto que estimula - de manera sobre todo indirecta- a los otros personajes para que se decidan a realizar un cambio en sus vidas. Sin embargo, Pablo se muestra incapaz de enfrentarse a sus propios sentimientos hacia Elvira, y él mismo acaba huyendo, al comprobar que ese contexto social le asfixia, concluyendo que allí no deja "nada", como Andrea en la novela de Carmen Laforet.

Otro dato que llama la atención, tanto en estas novelas de Martín Gaite y Laforet como en otras de la época, es la frecuencia con que las protagonistas son chicas huérfanas de madre: así, por ejemplo, Andrea en Nada, Natalia en Entre visillos (mientras que la madre de Elvira aparece como una sombra en la novela, pues apenas tiene protagonismo), Valba en Los Abel de Ana María Matute, o Carola en Perdimos la primavera, de Eugenia Serrano. En el caso de Magdalena (Lena), protagonista de la novela de Dolores Medio Nosotros, los Rivero, el rechazo a la madre se hace explícito: "Lena no la quiso nunca: Su madre no había sabido comprenderla, y ella casi la odiaba" (Medio 1953: 291). Lena identifica a su madre con la moral represiva del nacionalcatolicismo y, por tanto, con la principal fuerza oponente a sus deseos de libertad e independencia, lo que ella concibe como el derecho a dirigir su propia vida. Cabe plantearse en este sentido a modo de hipótesis si esta recurrencia tendrá alguna vinculación con el sentimiento de "matrofobia", la pérdida de fuerza, en el contexto de posguerra, por parte 
de las madres reales para ejercer de modelos de mujer atractivos a los ojos de sus jóvenes hijas, en este caso escritoras que rondan los veinte años cuando escriben estas novelas, y de ahí el rechazo, que lleva incluso a suprimirlas de los mundos de ficción que crean, dejando de este modo literalmente huérfanas a las protagonistas.

En la novela de C. Martín Gaite, las mujeres ven pasar la vida "entre visillos", cercenadas sus posibilidades vitales por el único modelo de mujer admitido socialmente, el de sacrificada madre y esposa, "ángel del hogar", fiel y obediente al marido, al que admira siempre por su mayor experiencia y conocimiento". Sólo las "chicas raras" se plantean en este contexto si no serán posibles otros modelos de mujer ${ }^{10}$. Así, por ejemplo, imagina Elvira, asomada al balcón:

Le hubiera gustado ver de golpe a sus pies una gran avenida con tranvías y anuncios de colores, y los transeúntes muy pequeños, muy abajo, que el balcón se fuera elevando y elevando como un ascensor sobre los ruidos de la ciudad hormigueante y difícil. Y muchas chicas venderían flores, serían camareros, mecanógrafas, serían médicos, maniquíes, periodistas, se pararían a mirar las tiendas y a tomar una naranjada, se perderían sus compañeros de trabajo entre los transeúntes, irían a tomar un tranvía para llegar a su barrio que estaba muy lejos (Ibid.: 128-129).

De modo semejante, otra "chica rara", Carola, protagonista de Perdimos la primavera (1952) de Eugenia Serrano, sueña con modelos de mujer diferentes a aquél en el que ha sido socializada:

Entrevista desde la infancia, la feminidad no debía ser más que un sueño de riqueza y frivolidad. Lita era la más descontentadiza. ¿Mujer? ¿Por qué ser mujer?

${ }^{9}$ De hecho, todo en esta novela produce la sensación de opresión, de angostura y constreñimiento vital: las conversaciones anodinas, insustanciales y repetitivas de estas chicas de provincias, la pequeñez de las preocupaciones que configuran su reducido mundo... Éste es sin duda uno de los logros más importantes de la novela, que logra transmitir esa atmósfera opresora en este relato que bien podría titularse también "Atrapadas" (en un mundo que no les gusta, pero del que no saben cómo salir...si es que quieren verdaderamente salir...si es que existe una salida).

${ }^{10}$ Sin embargo, hasta las que se muestran más conformistas con los modelos aprendidos y las normas sociales establecidas, acaban por acusar en algunos momentos la estrechez de los límites entre los que se mueven sus vidas. Este es el caso por ejemplo de Goyita, que se imagina del siguiente modo el invierno que se avecina: "Todo lo del verano se les desmoronaba como si no lo hubieran vivido. San Sebastián, el chico mejicano, Marisol en el Casino con sus trajes diferentes acaparándose a Toñuca, su amiga íntima, y a Manolo Torre. Ahora estaban de cara al invierno interminable. Tardes enteras yendo al corte y a clase de inglés, esperando sentada a la camilla a que Manolo viniera de la finca y se lo dijeran las amigas, o que alguna vez la llamaran por teléfono" (Martín Gaite 1991: 119). 
¿No era más bonito que las pieles, que los perfumes, que los caballeros cinematográficos, el poder vestirse por abajo, y cruzar las piernas siempre, sin preocupación de "parecer honesta"? ¿No es más hermoso ser general, papa, torero, o siquiera obispo? ¿No resultaba, según se desprendía de la lectura de todos los cuentos y novelas, y la asistencia a todos los espectáculos, mucho más entretenido, más personal y arrebatador el papel de hombre? ¡Si pudieran cambiar la papeleta que les tocó en la lotería del sexo! Porque los mejores puestos de la vida, los de protagonista, correspondían siempre a los papeles masculinos (Serrano 1952: 85-86).

En lo que respecta a las pautas marcadas por la moral del nacionalcatolicismo acerca de cómo debían ser las relaciones entre mujeres y hombres, Carmen Martín Gaite señala que la represión sexual no era la cuestión más grave en este sentido, sino la "represión de la sinceridad" — como puede verse en la relación entre Elvira y Pablo en Entre visillos-, que los condena a ser enemigos y los imposibilita para establecer una verdadera amistad:

[...] aquella represión sexual, aunque pudo efectivamente provocar la infelicidad de muchos matrimonios, no era ni mucho menos tan grave como otro fenómeno más desatendido y subyacente al primero: el de la represión de la sinceridad entre los hombres y mujeres a lo largo de los años de trato jalonaban su permanencia en aquella "escuela del noviazgo" tan decantada [...] Más que las trabas que se les ponían a los novios de posguerra para besarse sin remordimientos y tener ocasión de conocer, antes de la boda, sus respectivos cuerpos, considero perniciosas las que se les pusieron, al amparo de la insinceridad, para llegar a ser amigos y conocer sus respectivos deseos, miedos, decepciones y esperanzas. En una palabra, para dejarse querer y ver por el otro en su verdad desnuda, no con arreglo a los datos falsos que se proporcionaban mediante la representación de un papel (Martín Gaite 1992a: 209-210).

\section{BIBLIOGRAFÍA CITADA}

Boixados, D. 1970. Aguas muertas. Madrid: Ediciones Punta Europa.

Castillo, S. (coord.). 2008. Monográfico: Antropología y Literatura. Revista de Antropología Social 17.

Comaroff, J. y J. Comaroff. 1991. Of Revelation and Revolution. Chicago: Chicago University Press.

De la Fuente, M. (ed.). 1994. Etnoliteratura. Un nuevo método de análisis en Antropología. Córdoba: Servicio de Publicaciones de la Universidad de Córdoba.

De la Fuente, M. y Ma A. Hermosilla (eds). 1997. Etnoliteratura: una antropología de ¡lo imaginario?. Córdoba: Servicio de Publicaciones de la Universidad de Córdoba.

Del Prado, J. 2000. Análisis e interpretación de la novela. Cinco modos de leer un texto narrativo. Madrid: Síntesis.

Douglas, M. 1991. Pureza y peligro. Madrid: Siglo XXI.

Fernández, C. 1979. "Entrevista con Carmen Martín Gaite". Anales de la Narrativa Española Contemporánea 4: 165-172. 
Fuente, I. 2002. Mujeres de la posguerra. De Carmen Laforet a Rosa Chacel: historia de una generación. Barcelona: Planeta.

Galvarriato, E. 1967. Cinco sombras. Barcelona: Destino.

Hermosilla, M. A.; A. Castaño y L. Díaz (coords.). 2005. Etnoliteratura: lecturas de la condición humana. Homenaje a Manuel de la Fuente Lombo. Revista de Dialectología $y$ Tradiciones Populares LX (1).

Jurado Morales, J. 2003. La trayectoria narrativa de Carmen Martín Gaite (1925-2000). Madrid: Gredos.

Laforet, C. 1945. Nada. Barcelona: Destino.

Lisón Tolosana, C. (ed.). 1995. Antropología y literatura. Zaragoza: Departamento de Educación y Cultura, Gobierno de Aragón.

Martín Gaite, C. 1963. Ritmo lento. Madrid: Destino.

Martín Gaite, C. 1980. "Carmen Martín Gaite - A Fondo", Entrevista de Joaquín Soler Serrano, RTVE.

Martín Gaite, C. 1982. La búsqueda de interlocutor y otras búsquedas. Barcelona: Destino.

Martín Gaite, C. 1991. Entre visillos. Barcelona: Destino.

Martín Gaite, C. 1992a. Usos amorosos de la posguerra española. Barcelona: Anagrama.

Martín Gaite, C. 1992b. "La chica rara", en Desde la ventana. Enfoque femenino de la literatura española: 101-122. Madrid: Espasa Calpe.

Martín Gaite, C. 1999. La hermana pequeña. Barcelona: Anagrama.

Matute, A. M. 1948. Los Abel. Barcelona: Destino.

Mayoral, M. 2003. "Comentario", en C. Martín Gaite, Entre visillos: V-XL. Madrid: Destino. Medio, D. 1953. Nosotros, los Rivero. Destino: Barcelona.

Pozuelo Yvancos, J.M. 1993. Poética de la ficción. Madrid: Síntesis.

Primo de Rivera, P. 1943. Primer Consejo Nacional del S.E.M. Madrid: Servicio Español de Magisterio.

Serrano, E. 1952. Perdimos la primavera. Barcelona: José Janés.

Fecha de recepción: 8 de abril de 2008

Fecha de aceptación: 14 de mayo de 2009 